\title{
Alphaviral Vectors for Gene Transfer into Neurons
}

\author{
Markus U. Ehrengruber* \\ Brain Research Institute, University of Zurich, \\ Winterthurerstrasse 190, CH-8057 Zurich, Switzerland
}

\begin{abstract}
Alphaviruses are small, enveloped positive-strand RNA viruses that have been successfully transformed into expression vectors in the case of Semliki Forest virus (SFV), Sindbis virus (SIN), and Venezuelan equine encephalitis virus. Compared to other viral vectors, their advantages are easy and fast generation of recombinant viral particles, rapid onset, and high-level transgene expression. When applied to neuronal tissue, SFV and SIN vectors possess the additional advantage of efficiently and preferentially transducing neurons rather than non-neuronal cells. This article gives an overview of the biology of SFV and SIN, their generation into expression vectors, and their application in neurobiology, with particular emphasis on the transduction of hippocampal neurons. In addition, it describes the more recent development of alphaviral vectors with decreased or absent cytotoxicity and lowered transgene expression, temperature-controllable gene expression, and altered host-cell specificity in the central nervous system (CNS). Finally, the review evaluates the use of SFV and SIN vectors in hippocampal tissue cultures vs recombinant lentivirus, adenovirus type 5, adeno-associated virus type 2, and measles virus.
\end{abstract}

Index Entries: Semliki Forest virus; Sindbis virus; RNA virus; expression vector; green fluorescent protein; hippocampus.

\section{Introduction}

Alphaviruses are enveloped (+)-strand RNA viruses of the togavirus family that are increasingly being applied as expression vectors. The most widely used alphaviral vectors are based

* Author to whom all correspondence and reprint requests should be addressed. E-mail: ehrengru@ hifo.unizh.ch on Semliki Forest virus (SFV), Sindbis virus (SIN), and Venezuelan equine encephalitis virus (VEE), which infect cells via the major histocompatibility class I molecule, laminin, and other receptors (1). The original SFV isolate (strain L10) was obtained from mosquitoes from the Semliki Forest, Uganda, in 1944 (2), while the original SIN isolate (strain AR339) stems from mosquitoes collected near Sindbis, Egypt, in 1952 (3); VEE was originally isolated from the brain of horses in the Guajira region 
of Venezuela (4). Since their initial identification, SFV and SIN have become the model alphaviruses, providing detailed knowledge of their molecular biology and replication in host cells. While initial viral vectors were based on DNA viruses (such as vaccinia virus, adenovirus, and adeno-associated virus), the molecular cloning of SFV and SIN as cDNAs has enabled the subsequent development of these RNA viruses into efficient, high-level expression systems.

In nature, alphaviruses cycle predominantly between mosquitoes and small mammals and birds. Wild-type SFV and SIN target neurons in the CNS, induce neuronal apoptosis, and cause encephalitis in rodents, sometimes with lethal outcome (5). Data from studies in mice and rats with replication-competent SFV and SIN indicate that neurotropism and neuronal survival are determined by both the viral strain and the age of the injected animals. While all strains cause fatal disease in newborn and suckling rodents, several strains (including SFV A7, its derivative SFV A7 [74] and SIN [AR339]) are avirulent for adult animals and cause limited CNS infection, which is cleared within 7-10 ds post-infection (6-9).

\section{Alphaviral Replication}

The first two thirds of the $11.8 \mathrm{~kb}$ long, capped RNA genome serve as mRNA for the polyprotein containing nonstructural proteins 1-4 (nsP1-4), which is post-translationally processed into the four proteins that are required for transcription and replication of the alphaviral RNA. NsP1 has methyl- and guanyltransferase activity; nsP2 is involved in the proteolytic processing of nsP1-4 and regulates viral RNA synthesis; and nsP4 is the viral RNA polymerase (1). NsP3 is a phosphoprotein (10) involved in alphaviral RNA replication (11), but its precise function remains unknown. Within the first hours of infection, the nsP123 polyprotein and nsP4 generate the negativestrand RNA that is complementary to the viral genome. Once the nsP123 polyprotein has been cleaved (through nsP2), the negative-strand RNA serves as a template for efficient synthesis of both new positive-strand genomic RNA, and subgenomic 26S RNA that encodes the viral structural proteins. The subgenomic RNA is translated into the polyprotein that is then processed into the capsid and spike proteins, p62 and E1. Owing to an encapsulation signal in the $n s P 1$ gene for SIN and nsP2 gene for SFV, capsid proteins assemble with genomic RNA molecules to form nucleocapsids, which then bud from the cell membrane where processed spike proteins have been inserted (1). Figure 1 gives a schematic overview of the alphaviral replication and virus assembly.

\section{Alphaviral Vectors: The Replicon System}

Vectors for SFV and SIN as well as the closely related VEE have been developed to express high levels of foreign genes in vitro and in vivo (12-15). Owing to their promiscuous usage of cell surface receptors for attachment, an extremely wide range of host cells, including most cell lines and many primary cultures from insect to mammalian cells, can be infected and successfully transduced $(16,17)$.

While fully replication-proficient alphaviral vectors have been used (18), a more common approach is the replicon system (see Fig. 2) in which the transgene in the "vector RNA" replaces the viral structural protein genes (13-15). Vector RNAs are self-replicating and are referred to as "replicons." They must be cotransfected with defective "helper RNA" to be packaged into infectious particles. Both vector and helper RNAs are obtained by in vitro transcription from plasmids containing their respective cDNAs. A vector RNA-encoding plasmid of the SFV system, pSFV2gen (19), is shown in Figure 3. It is based on pSFV1 (13) but contains a multiple-cloning site with additional unique restriction sites.

Defective helper RNAs have a large deletion in nsP1-4 and are not self-replicating, but can be replicated and transcribed by the nsPs pro- 


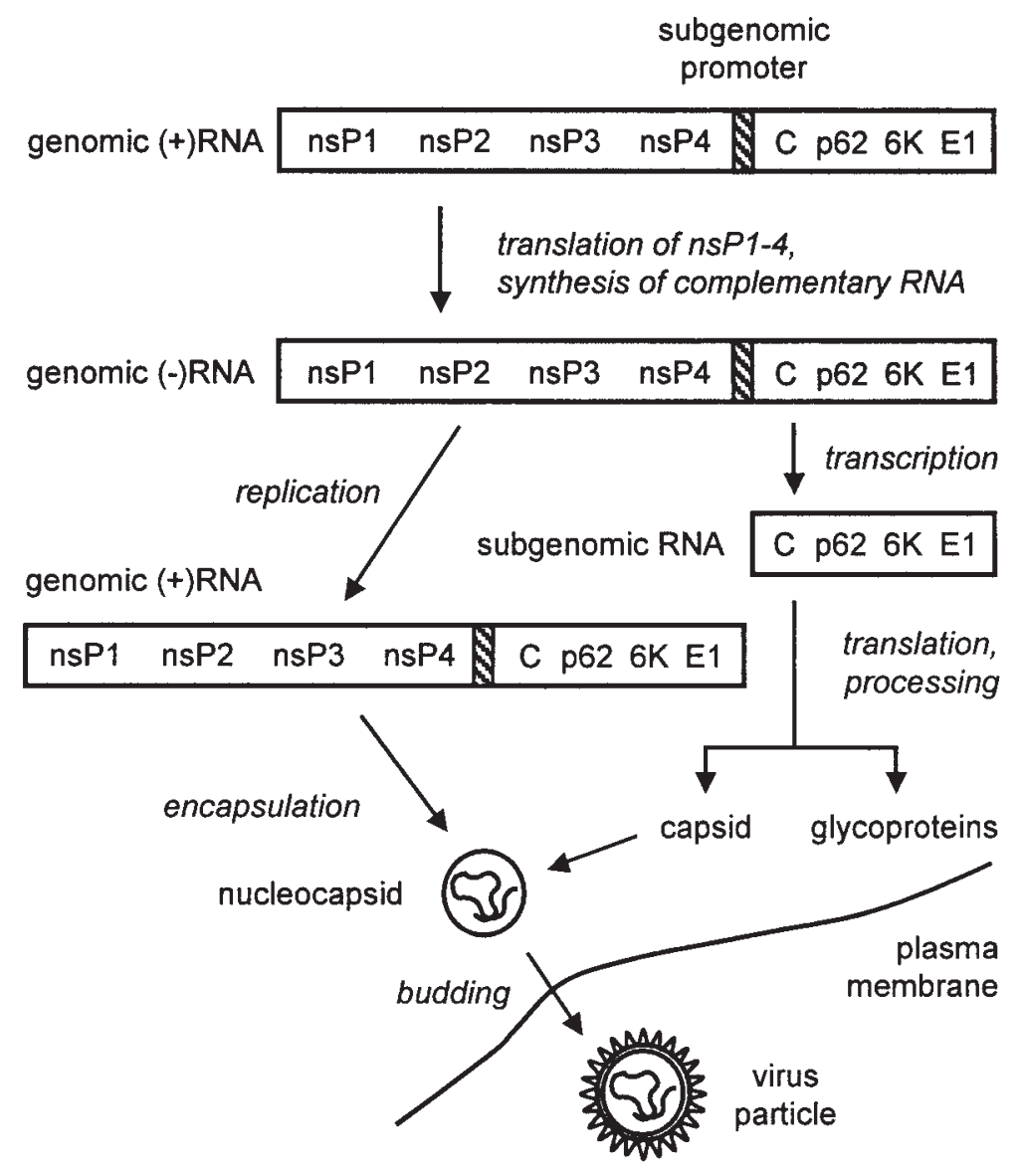

Fig. 1. Alphaviral replication and assembly. Upon attachment of the viral particle to the cell and entry via endocytosis, the viral nucleocapsid is released into the cytoplasm. Binding of the nucleocapsid to ribosomes then triggers the uncoating process that releases the genomic (+)-strand RNA into the cytoplasm. The genomic RNA is then translated into the nsP1-4 preprotein that synthesizes the complementary (-)-strand genome. When nsP1-4 is cleaved into the separate proteins, many copies of both (+)-strand genomic and subgenomic RNA are formed. The subgenomic RNA is translated into the capsid protein $(\mathrm{C})$ and the envelope proteins (p62, the precursor of the E2 and E3 spike proteins; the 6K protein; and E1). Owing to the packaging signal in the nsP region of the genome, the genomic RNA is bound to capsid proteins, thereby forming the nucleocapsid. Interaction of the nucleocapsid with envelope glycoproteins (spikes), which have penetrated into the host cell membrane, liberates the virus particle from the host cell. (Modification of the figure kindly provided by Dr. Sondra Schlesinger, Washington University School of Medicine, St. Louis, USA.)

vided by the replicons. Helper subgenomic RNAs are translated to provide the capsid and spike proteins for replicon assembly under conditions in which helper RNAs are not packaged. Alternatively, the capsid and spike proteins can be supplied from stably transfected cells line (20). Packaged replicons derived by this approach have been termed "suicide vectors" (21) because they infect target cells without the capability of forming new infectious particles (as the introduced replicon genome is lacking the structural protein genes).

A fully DNA-based SFV expression system employs vector and helper plasmids with the 


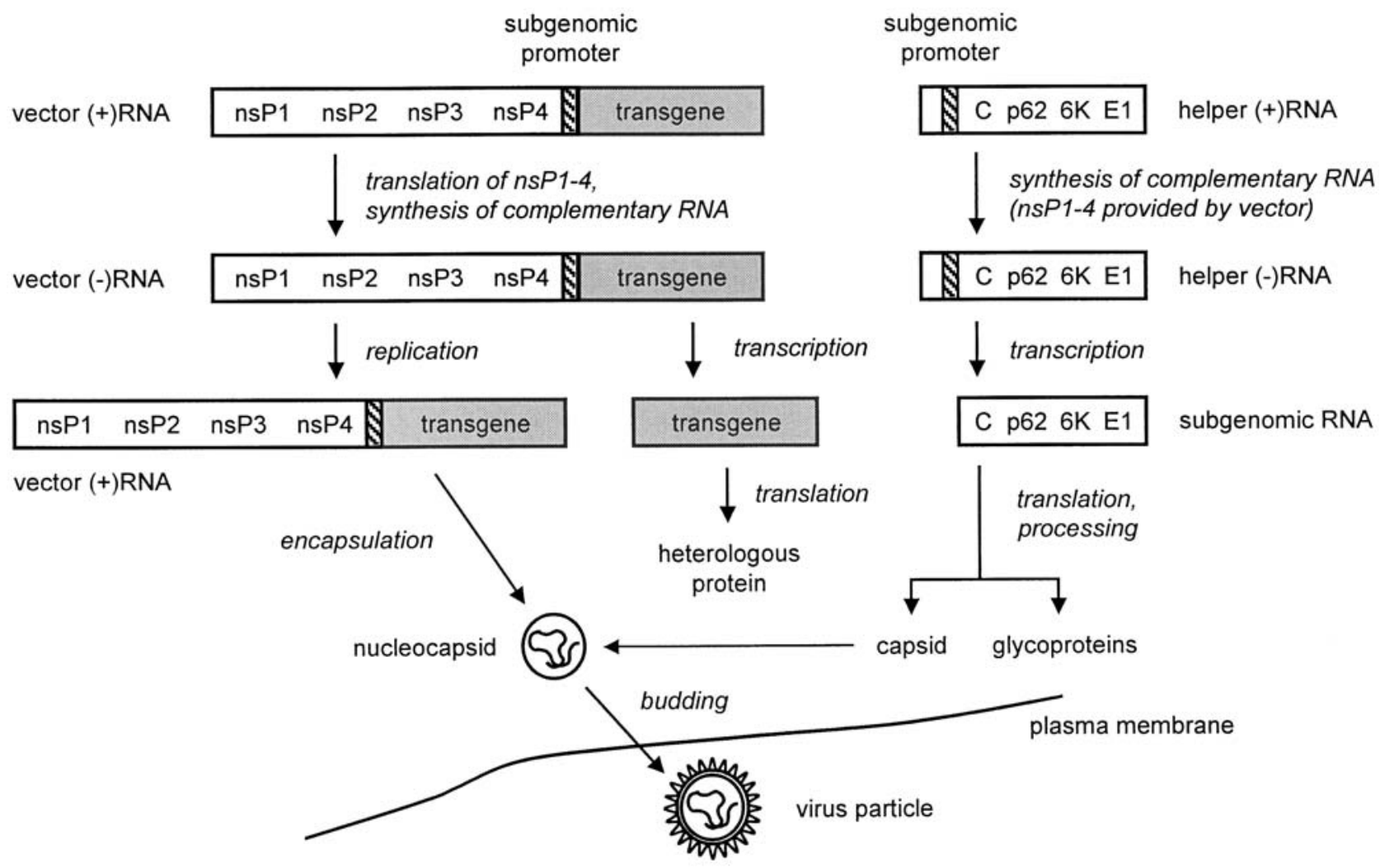

Fig. 2. Packaging of SFV and SIN replicons. Vector RNA encoding nonstructural proteins 1-4 (nsP1-4) and the transgene (shaded) under the control of the $26 \mathrm{~S}$ subgenomic RNA promoter (hatched), and defective helper RNA (encoding the structural alphavirus proteins downstream of the subgenomic RNA promoter) are obtained by in vitro transcription from their respective cDNAs and co-transfected into BHK cells. Only the vector RNA contains the packaging signal required for encapsidation into the nucleocapsid. Within the cytoplasm, vector RNA replication occurs through the action of nsP1-4. In parallel, the defective helper RNA is replicated and transcribed by nsP1-4, and the capsid protein C, 6K protein, glycoprotein E1, and precursor protein p62 (which is later cleaved into the E2 and E3 spike proteins) are translated. Capsid proteins package only vector RNA, while spike proteins are incorporated into the cell membrane. Nucleocapsids dock to the cell membrane where spike proteins have been incorporated, thus allowing the budding of virus particles.

prokaryotic SP6 RNA polymerase promoter (for in vitro transcription) replaced by an RNA polymerase II-dependent promoter, permitting expression in eukaryotic cells (22). The viral titers obtained by co-transfection of these plasmids into baby hamster kidney 21 (BHK) and COS-1 cells, however, are significantly lower than the titers obtained by co-electroporation of vector and helper RNAs.
In a different approach, the helper RNA, in addition to the vector RNA, similarly contains a packaging signal, resulting in the co-packaging of both vector and helper RNA into infectious particles. Virus particles derived by this method have been successfully used as an efficient expression cloning system for receptors and other membrane proteins, as well as for secreted and intracellular proteins (23). 


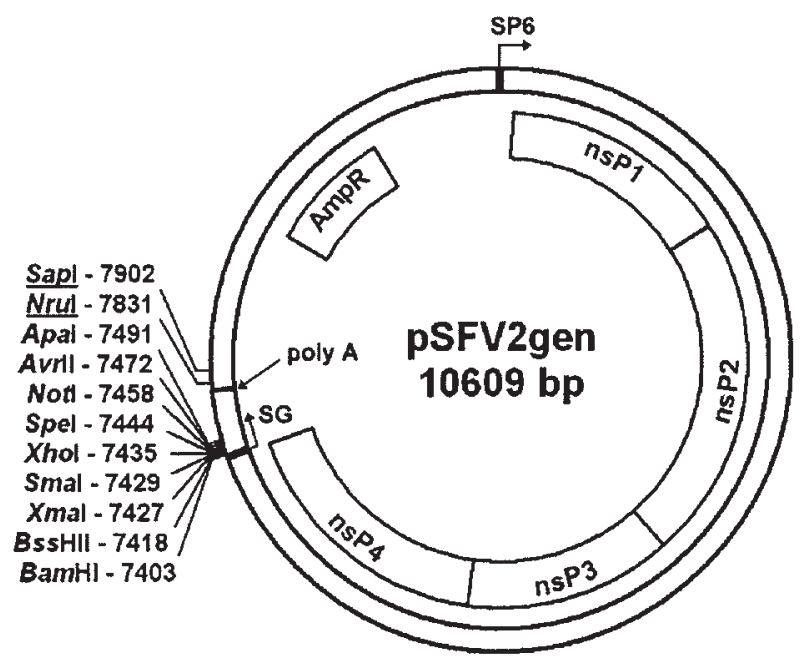

Fig. 3. Topological map of the pSFV2gen vector plasmid. Nucleotides are numbered with the first nucleotide of the cDNA derived from SFV4 genomic RNA defined as 1. The locations of the nsP1-4 genes encoding the nonstructural proteins, the ampicillin resistance gene, the SP6 promoter for in vitro transcription, the alphaviral 26S subgenomic RNA promoter (SG), and the poly-A sequence are indicated. The graph contains the unique restriction sites of the multiple cloning site for inserting genes of interest, as well as the linearization sites (underlined) for in vitro transcription.

\section{Biosafety}

While other alphaviruses such as VEE and rubella virus are human pathogens, wild-type SFV and SIN normally cause less severe infections in humans, with SIN leading to mild fever, joint-pain, and rash (5). For SFV, human infection is relatively common, but this has been linked to disease in only two occasions (5). This explains why SFV is classified as biosafety level 3 in the USA, but with the condition that most activities (including the work with SFV vectors) can be carried out at level 2, which is also the biosafety level for SIN (US HHS Publication no. CDC 93-8395, 1993) (24). In the European Union and in Switzerland, SFV and SIN are classified as biosafety level 2 (EC Council Directive 93/88/EEC, 1993; statement of the Swiss expert committee for biosafety on the classification of work with genetically modified viral vectors, August 2001).

SFV and SIN expression systems using replicons (cf, above) consist of two components: the expression vector and the helper plasmid. When the original SFV helper plasmid is used, fully replication-proficient viral particles may form by homologous recombination in $\mathrm{BHK}$ cells. In co-transfections of SFV expression vectors with the pSFV-Helper2 plasmid (91), however, no infectious virus particles can arise due to point mutations in the structural genes, which prevent cleavage of the p62 precursor protein into functional E2 and E3 envelope glycoproteins. The resulting SFV particles are noninfectious until activated with $\alpha$-chymotrypsin. Therefore, viral vectors packaged with pSFVHelper2 have been grouped into biosafety level 1 classifications in several European countries, including Germany and Switzerland (http:/ / www.rki.de/GENTEC/ZKBS/ZKBS. HTM; statement of the Swiss expert committee for biosafety on the classification of work with genetically modified viral vectors, August 2001).

\section{Applications in Neurobiology}

\section{Transduction of Neurons}

Both SFV and SIN vectors have been used successfully to transduce neurons in primary and tissue cultures (see Fig. 4) and in vivo (e.g., refs. 25-32). Organotypic cultures of hippocampal slices $(33,34)$ represent a highly applicable preparation that permits rapid tests for recombinant proteins in a system that is more similar to the in vivo situation than cultures of dissociated neurons. SFV and SIN vectors deliver genes efficiently to neurons in organotypic hippocampal slices prepared from neonatal and postnatal rats (see Fig. 4A,B; refs. $27,28,35)$. In collaboration with my colleague Kenneth Lundstrom, I successfully established a standardized protocol for the application of alphaviral vectors in this test system $(36,37)$. 

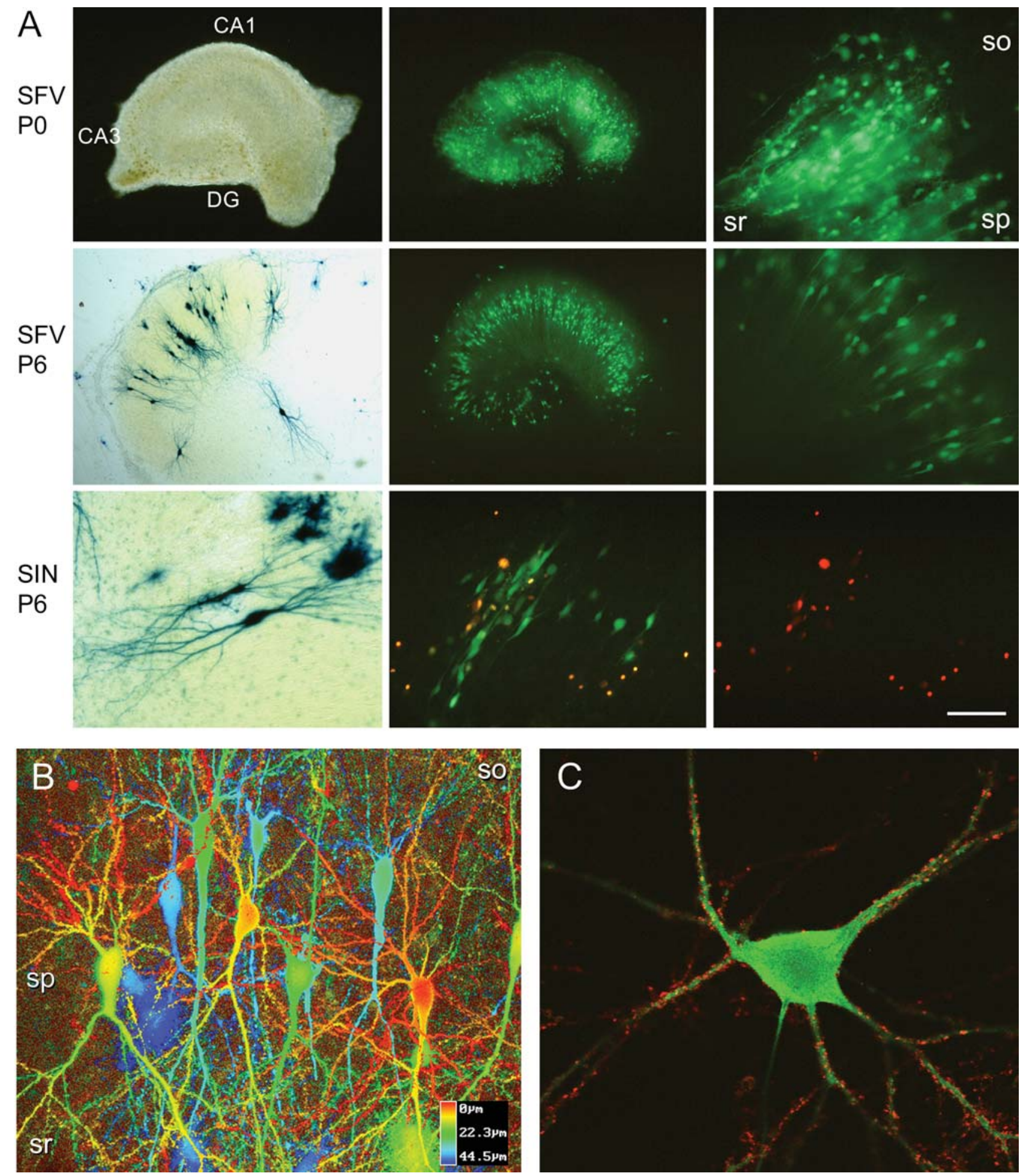

Molecular Neurobiology

Volume 26, 2002 
Table 1

Advantages and Disadvantages of Conventional SFV and SIN Vectors Compared to Other Viral and Non-Viral Transduction Techniques

Advantages Disadvantages

Rapid production

Extremely high viral titers obtained (stocks are therefore used at $\leq 10,000$-fold dilution)

Preferential and efficient infection of neurons Inhibition of host cell protein synthesis and cytotoxicity Not applicable for long-term gene transfer

Fast gene expression (within hours) High transgene expression levels

Note that more recently developed, mutant alphaviral vectors eliminate specific disadvantages (cf Table 3).

Fig. 4. Transduction of cultured rat hippocampal slices (A,B) and primary rat hippocampal neurons (C) by using SFV and SIN vectors. (A) Rat hippocampal slices from P0 and P6 rats were cultured for 1 and $45 \mathrm{~d}$ (P0 vs P6, respectively) and then infected with 100- to 10,000-diluted SFV and SIN encoding enhanced green fluorescent protein (GFP) or E. coli $\beta$-galactosidase (LacZ). Dark field (top left) and fluorescence micrographs of living slices were taken at $2 \mathrm{~d}$ post-infection, whereas bright field images were obtained from slices fixed and stained for LacZ expression at $1 \mathrm{~d}$ post-infection. Transduced cells appear in green and blue for GFP and LacZ, respectively. Propidium iodide staining was performed on living slices at $5 \mathrm{~d}$ post-infection; an FITC filter set with a long-pass emission filter revealed both infected cells and propidium iodide-positive (red), non-viable cells (bottom middle), whereas a rhodamine filter set revealed only propidium iodide fluorescence (bottom right). Note that most infected cells exclude propidium iodide, and therefore, appear to be intact. Abbreviations: DG, dentate gyrus; so, stratum oriens; sp, stratum pyramidale; sr, stratum radiatum. Bar: $330 \mu \mathrm{m}$ (left and middle panels of top and middle row) and $80 \mu \mathrm{m}$ (remaining panels). Magnifications are from CA1 regions, except for the bottom left panel which shows infected CA3 pyramidal cells. (B) Confocal image of the CA1 region from a rat hippocampal slice culture at $2 \mathrm{~d}$ after infection with an SFV expressing GFP. The color code indicates the depth of the location of GFP-positive cells within the slice. Note that most GFP-positive cells are pyramidal cells (image kindly provided by Dr. R. Anne McKinney, University of Zurich, Switzerland). (C) Confocal image of a rat hippocampal neuron in culture, $1 \mathrm{~d}$ after infection with an SFV vector expressing GFP. GFP fluorescence is shown in green, while in vivo labeling of active boutons with an anti-synaptotagmin-I antibody is shown in red (image kindly provided by Dr. Antonio Malgaroli, Scientific Institute San Raffaele, Milano, Italy). 
Table 2

Proteins that Have Been Functionally (Over)expressed with SFV and SIN Vectors in Neurons

\begin{tabular}{|c|c|c|}
\hline Recombinant protein & Comments & Refs. \\
\hline \multicolumn{3}{|l|}{ Intracellular proteins } \\
\hline$\beta$-galactosidase & Reporter molecule & $(27,29,30,62)$ \\
\hline GFP & Reporter molecule & $(27,30,32,63)$ \\
\hline NEDD-2 & Cysteine protease & $(64)$ \\
\hline Aspartylglucosaminidase & Enzyme & (65) \\
\hline p16 ${ }^{\text {ink4 }}, \mathrm{p} 21^{\text {waf/cip }}, \mathrm{p} 27^{\mathrm{kip} 1}$ & Cyclin-dependent kinase inhibitors & $(66)$ \\
\hline Cdk4, Cdk6 (dominant-negative) & $\mathrm{G}_{1}$ cyclin-dependent kinases & (66) \\
\hline CaMKII (truncated) & Kinase & $(67)$ \\
\hline Munc13-1, Munc 18-1 & Synaptic vesicle priming proteins & $(68,69)$ \\
\hline Snapin & Binds synaptic protein SNAP-25 & (70) \\
\hline Syntaphilin & SNARE assembly regulator & (71) \\
\hline Homer-1a and $1 c$ & Postsynaptic scaffolding protein & $a$ \\
\hline \multicolumn{3}{|l|}{ Membrane proteins } \\
\hline $\mathrm{GABA}_{\mathrm{A}}$ receptor $\alpha 1$ and $\beta 2$ subunits & Ligand-gated ion channel & $(48,72)$ \\
\hline Serotonin $5-\mathrm{HT}_{3}$ receptor & Ligand-gated ion channel & $(73)$ \\
\hline $\mathrm{P}_{2} \mathrm{X}_{2}$ receptor & Ligand-gated ion channel & (74) \\
\hline Calcium channel $\beta 4$ subunit & Calcium channel regulator & (26) \\
\hline GluR1, GluR2, GluR4 & AMPA receptor subunits & $(31,40,75-77)$ \\
\hline GluR2 C-term & Blocks Pick1-GluR2/3 interaction & $(78)$ \\
\hline VGLUT1/BNP1, VGLUT2/DNPI & Vesicular glutamate transporters & $(79,80)$ \\
\hline Connexin 36 & Increases intercellular coupling & $a$ \\
\hline SNAP-25 & Synaptic protein & $(81,82)$ \\
\hline SGT & Synaptic vesicle surface protein & (83) \\
\hline GFP-tagged pleckstrin homology domain & Indicator of intracellular $\mathrm{IP}_{3}$ dynamics & $(84)$ \\
\hline Amyloid precursor protein (APP) & Cleaved into $\beta$-amyloid peptide & (85) \\
\hline Presenilin-1 & Associated with familial AD & $(86)$ \\
\hline Catechol O-methyltransferase & Membrane-bound enzyme & (87) \\
\hline Rab8 & Membrane-associated GTPase & (25) \\
\hline Neprilysin & Membrane-associated metalloendopeptidase & $(88)$ \\
\hline VIP21 & Integral membrane protein & (25) \\
\hline polymeric immunoglobulin receptor & Binds immunoglobulins $\mathrm{A}$ and $\mathrm{M}$ & (89) \\
\hline F protein & Measles virus glycoprotein & $a$ \\
\hline
\end{tabular}

${ }^{a}$ Own, unpublished data.

Compared to other viral vectors, biolistic and lipid-based transfection methods, SFV, and SIN vectors cause rapid, high-level, and efficient transduction ( $>95 \%$ in primary neurons, see Fig. 4C). It is also beneficial for many studies that conventional SFV and SIN vectors preferentially transduce neurons rather than non-neuronal cells, causing pyramidal cells and interneurons, in hippocampal slice cultures, to constitute approx $90 \%$ of all cells positive for green fluorescent protein (GFP; see Fig. 4B) $(27,28)$.

Aside from their advantages (see Table 1), wild-type alphaviral vectors $(13,15)$ retain the disadvantage of inhibiting host cell protein synthesis, which eventually causes cell death. While neurotoxic effects appear relatively fast (within 1-2 d) and are readily observed in cultures of dissociated hippocampal neurons $(25,38,39)$, they are delayed by several days in 
hippocampal slice cultures. Based on propidium iodide exclusion experiments (cf, Fig. 4A, bottom middle and right panels) and electrophysiological tests of passive and active membrane properties (i.e., resting membrane potential and conductance, action potential generation, firing accommodation, and hyperpolarization-induced currents), we found pyramidal cells in this preparation to survive for $2-5 \mathrm{~d}$ post-infection $(27,28)$. In any case, as alphaviral GFP expression in tissue cultures is fast (detectable within 4-6 h) and transient (peaking at $1 \mathrm{~d}$ post-infection) (28), the time window to examine transgene effects suffices for many physiological studies, including the microscopical and electrophysiological analysis of synaptic function (e.g., Fig. 4C; ref. 40), and the real-time investigation of activity-dependent morphological changes (32).

Table 2 summarizes different transgenes that have been introduced into hippocampal and other neurons by using packaged SFV and SIN replicons. While it lists many intracellular and membrane proteins that could be expressed in a functional manner, our attempts to functionally overexpress the transcription factors EGR1 and EGR2 with the less cytopathic SFV(PD) mutant $(38,39)$ were not successful. The analysis with an anti-EGR1 antibody revealed the presence of immunoreactive protein in the cytoplasm rather than the nucleus of infected cells; and functional tests for transactivation of EGR1-dependent luciferase reporter gene expression were not successful (M.J. Fend, K. Lundstrom, and M.U. Ehrengruber, unpublished data). By contrast, when inserted into adenoviral vectors, exactly the same EGR1 cDNA was able to induce EGR1-dependent gene expression (41). These results indicate that the present alphaviral vectors may not be applicable for the functional study of specific transcription factors. Another report with a GFP-tagged transcription factor (ATF-4) overexpressed by SFV did not examine whether ATF-4 transactivating function was retained in infected cells (42).

\section{Heterologous Expression of Neuronal Proteins}

Owing to the intracellular amplification processes inherent in alphaviral genome replication, SFV and SIN vectors generate extremely high transgene expression levels in infected cells. These levels can be problematic in cases where the transgene product has cytotoxic effects (as in the human neurokinin-1 receptor [43]) or because it does not match physiological levels. On the other hand, alphaviral vectors are particularly advantageous when applied in cell lines for generating high amounts of recombinant protein required (e.g., for the drug screening of receptors and the purification of proteins for structural studies and crystallization. Compared to the baculovirus system, which generates similar recombinant protein levels, alphaviral vectors possess the advantage of functioning well in mammalian cells.

Alphaviral vector systems have been particularly useful for the heterologous expression of receptors, including $G$ protein-coupled receptors such as the metabotropic glutamate receptors mGluR2, 3, 4, and $8(19,44,45)$, the human neurokinin-1 receptor $(43,46)$, and the $\alpha_{1 b^{-}}$ adrenergic receptor (47). Radioligand binding on intact cells and isolated cell membranes revealed extremely high expression levels, with 3-10 million receptors per cell and 50-200 pmol recombinant receptor per mg total protein. An intact functional coupling of the overexpressed receptors to $G$ proteins in response to agonists has been tested via measurements of, e.g., GTP $\gamma S$ binding (44), intracellular $\mathrm{Ca}^{2+}$ mobilization (43), and inositol phosphate accumulation (47).

In specific applications, the heterologous expression of distinct proteins, possibly at approximately equal ratios, within a given cell is required. For example, it has been shown for the $\mathrm{GABA}_{\mathrm{A}}$ receptor that $\alpha 1$ or $\beta 2$ subunits, when expressed alone, are retained in the endoplasmic reticulum, whereas co-expression of both subunits permits $\mathrm{GABA}_{\mathrm{A}}$ receptor access to the plasma membrane (48). Separate 
genes can be introduced into the same cell by co-infection with different viral vectors $(47,48)$, the use of internal ribosomal entry site (IRES) sequences (67), and additional $26 \mathrm{~S}$ subgenomic RNA promoters (18).

\section{Identification of Infected Neurons Using GFP}

The function of transduced neurons is generally compared to one of uninfected control neurons (as well as to one of neurons infected with a control virus expressing, e.g., GFP) to determine the effect of the expressed transgene. This comparison is done ideally in the same population of cells, i.e., the same slice culture or the same Petri dish. Electrophysiological recordings, as well as other measurements from infected cells, thus require the identification of (living) cells that have been genetically modified. This is normally achieved by using GFP as a reporter molecule.

Three GFP-based approaches have been employed in combination with alphaviral vectors. The most common method is the generation of GFP fusion proteins where the gene of interest is fused to the GFP cDNA. This strategy, however, may be problematic as the attachment of the GFP domain can alter transport, localization, and function of the overexpressed protein. A second approach is the use of an internal ribosomal entry site (IRES) sequence between the gene of interest and the GFP cDNA, permitting separate expression of both genes. Our experiments using IRESdependent GFP expression, however, revealed relatively weak GFP fluorescence and allowed identification of infected pyramidal cells in organotypic hippocampal slices at only $3 \mathrm{~d}$ post-infection. A third method is to drive GFP expression separately under the control of an additional subgenomic alphaviral 26S promoter downstream of the gene of interest. This procedure, in our hands, resulted in sufficiently high GFP fluorescence levels to allow for electrophysiological recordings from GFPpositive primary neurons at $1 \mathrm{~d}$ post-infection. The second and third approaches, of course, can generally be used to express two or more transgenes as separate proteins, which may be required, e.g., for the expression of heteromeric proteins such as ligand-gated ion channels.

\section{Alphaviral Vector Development}

As summarized in Table 1, wild-type alphaviral vectors may be problematic because of 1) cytotoxicity; 2) short-term expression due to cytotoxicity and/or transient nature of the viral RNA; 3) no choice of promoter; and 4) in certain cases, extremely high expression levels. The development of alternative SFV and SIN vectors focuses on these negative properties by introducing specific mutations in the nsP1-4 genes that control viral replication and expression. Tables 3 and 4 give an overview of the modified alphaviral vectors and indicate their transduction characteristics in cell lines and neurons.

\section{Non-Cytopathic Vectors}

Spontaneous mutations discovered in the nonstructural genes, particularly in nsP2 and nsP4, have dramatic effects on the viral pathogenicity. Mutations in $n s P 2$ of SIN have produced viruses (49) and replicons (49-51) with greatly reduced cytotoxicity in cell lines (see Table 3). The majority of the mutants had a single change at amino acid 726 . For example, a change at this site from Pro to Ser produced replicons that had reduced levels of RNA replication, and therefore, also lower cytopathogenicity (49). The change from Pro to Leu led to a further reduction in both RNA synthesis and cytotoxicity (50). Replication-persistent replicons with ongoing viral multiplication were generated by random mutagenesis of $n s P$ genes in SIN and SFV vectors containing the neomycin resistance gene; once again they had either deletions or point mutations in nsP2 (51). All of these experiments were performed in cell lines (see Table 3), with mitosis of infected cells. In general, persistent infections appeared to be correlated with a lack of interferon production or the production of other potential cytokines. 
Table 3

Mutant SFV and SIN Replicons and Their Transduction Characteristics in Cell Lines Compared to the Conventional, Wild-Type Vectors SINrep5 (15) and SFV1 (13)

\begin{tabular}{|c|c|c|}
\hline Vector & Characteristics & Refs. \\
\hline $\mathrm{SIN}\left(\mathrm{nsP} 2_{\mathrm{A} 1 \mathrm{E}}\right)$ & $\begin{array}{l}\text { Non-cytopathic in BHK cells, establishes } \\
\text { persistent infection }\end{array}$ & $(51)$ \\
\hline SIN(nsP2P726S) & $\begin{array}{l}\text { Less cytopathic in BHK cells, noncytopathic } \\
\text { in mouse and human cell lines, higher } \\
\text { expression in BHK cells }\end{array}$ & $(49)$ \\
\hline $\mathrm{SIN}(\mathrm{nsP} 2 \mathrm{P} 726 \mathrm{~L} / \mathrm{T})$ & $\begin{array}{l}\text { Noncytopathic in all cell lines tested, establish } \\
\text { persistent infections in BHK, Vero and CHO } \\
\text { cells }{ }^{a}\end{array}$ & $(50,51,90)$ \\
\hline $\mathrm{SIN}\left(\mathrm{nsP} 2 \mathrm{P} 726 \mathrm{snsP} 4_{\mathrm{G} 153 \mathrm{E}}\right), \mathrm{pCytTS}$ & $\begin{array}{l}\text { Temperature-inducible, DNA-based expression } \\
\text { system in BHK, CHO-K1, C2C12, COS-7, } \\
\text { and HEK } 293 \text { cells }^{a}\end{array}$ & $(57)$ \\
\hline $\begin{array}{l}\text { SFV(nsP2L10T), SF2A; SFV(nsP2 }{ }_{\Delta \mathrm{D} 469)}, \\
\text { SF1B; SFV(nsP2L713P), SF2C }\end{array}$ & $\begin{array}{l}\text { Noncytopathic in BHK cells, establish persistent } \\
\text { infection }\end{array}$ & $(51)$ \\
\hline SFV(nsP2S259P,R649D), SFV(PD) & $\begin{array}{l}\text { Less cytopathic in BHK, HEK 293, and } \\
\text { CHO-K1 cells, higher expression, reduced } \\
\text { viral titers }\end{array}$ & $(38,39)^{b}$ \\
\hline SFV(nsP2S259P,R650D,L713P), SFV(PD713P) & $\begin{array}{l}\text { Noncytopathic in BHK cells, temperature- } \\
\text { sensitive, expresses at } 31^{\circ} \mathrm{C} \text { but not at } 37^{\circ}, \\
\text { higher expression, low viral titers }\end{array}$ & $c$ \\
\hline $\begin{array}{l}\left.\text { SFV(nsP2S259P,R649DnsP4 } 4_{\text {G153E }}\right) \\
\text { SFV(PDE } 153)\end{array}$ & $\begin{array}{l}\text { Temperature-sensitive in BHK cells, expresses } \\
\text { at } 31^{\circ} \mathrm{C} \text { but little at } 37^{\circ}\end{array}$ & (39) \\
\hline $\begin{array}{l}\left.\text { SFV(nsP2S259P,R649DnsP4 } 4_{\mathrm{G} 324 \mathrm{E}}\right) \\
\text { SFV(PDE }\end{array}$ & $\begin{array}{l}\text { Temperature-sensitive in } \mathrm{BHK} \text { cells, expresses } \\
\text { at } 31^{\circ} \mathrm{C} \text { but little at } 37^{\circ}\end{array}$ & (39) \\
\hline $\begin{array}{l}\left.\text { SFV(nsP2S259P,R649D,M780TnsP4 } 4_{\mathrm{G} 153 \mathrm{E}}\right) \\
\text { SFV(PDTE) }\end{array}$ & $\begin{array}{l}\text { Temperature-sensitive in BHK cells, expresses } \\
\text { at } 31^{\circ} \mathrm{C} \text { but not at } 37^{\circ} \text {, achieving higher } \\
\text { expression }\end{array}$ & (39) \\
\hline SFV(A774nsP) & $\begin{array}{l}\text { Temperature-sensitive in BHK cells, } \\
\text { transduces } \sim 100 \text {-fold more cells at } 31 \text { vs } 37^{\circ} \mathrm{C}\end{array}$ & $d$ \\
\hline $\begin{array}{l}\text { SFV(26S-M5), SFV(26S-M1), } \\
\text { SFV(26S-M3) }\end{array}$ & $\begin{array}{l}\text { Decreased transgene expression levels }(1,3, \\
\text { and } 30 \% \text { of wild-type, respectively) }\end{array}$ & $(58)$ \\
\hline
\end{tabular}

With regard to neuronal infection (see Table $4)$, the introduction of known temperaturesensitive mutations into nsP2 and nsP4 reduced the cytotoxicity of SFV vectors in primary hippocampal neurons (39). Furthermore, studies on replication-competent SFV revealed a point mutation (Arg649Asp) in the nuclear localization signal of nsP2 to confer lower neurovirulence in mice $(52,53)$. When we combined a similar mutation in the nsP2 nuclear localization signal (Arg650Asp) with an additional mutation in nsP2 (Ser259Pro), we obtained a vector, SFV(PD), that was less cytopathic and caused increased transgene expression in mammalian cell lines, primary hippocampal and cortical neurons, and organotypic hippocampal slices $(38,39)$ (K. Lundstrom, A. Abenavoli, A. Malgaroli, and 
Table 4

Transduction Characteristics of SFV Replicons in Hippocampal and Other Neurons

\begin{tabular}{|c|c|c|}
\hline Vector & Characteristics & Refs. \\
\hline \multirow[t]{3}{*}{ Conventional SFV ${ }^{a}$} & $\begin{array}{l}\text { Infects primary rat hippocampal neurons, } \\
\text { cytotoxic after }>8-24 \mathrm{hs}\end{array}$ & $(25,26)$ \\
\hline & $\begin{array}{l}\text { Targets pyramidal cells and interneurons in rat } \\
\text { hippocampal slices, neurons tolerate infection for } 2-5 \mathrm{~d}\end{array}$ & $(27,28)$ \\
\hline & In vivo, infects striatal neurons in rat brain & (29) \\
\hline \multirow[t]{2}{*}{ SFV(nsP2S259P,R650D), SFV(PD) } & $\begin{array}{l}\text { Less cytopathic in primary rat hippocampal } \\
\text { and cortical neurons, higher expression }\end{array}$ & $(39)^{b}$ \\
\hline & $\begin{array}{l}\text { Targets pyramidal cells and interneurons in rat } \\
\text { hippocampal slices }\end{array}$ & $(28)$ \\
\hline $\begin{array}{l}\text { SFV(nsP2S259P,R650D,L713P), } \\
\text { SFV(PD713P) }\end{array}$ & $\begin{array}{l}\text { Transduces pyramidal cells in rat } \\
\text { hippocampal slices }\end{array}$ & $c$ \\
\hline $\begin{array}{l}\left.\text { SFV(nsP2S259P,R649DnsP4 }{ }_{\text {G153E }}\right) \\
\text { SFV(PDE153) }\end{array}$ & $\begin{array}{l}\text { Targets interneurons at } 31^{\circ} \mathrm{C} \text {, but both pyramidal } \\
\text { cells and interneurons at } 37^{\circ} \mathrm{C} \text { in rat } \\
\text { hippocampal slices }\end{array}$ & $(39)$ \\
\hline $\begin{array}{l}\left.\text { SFV(nsP2 }{ }_{\text {S259P,R649DnsP4 }}{ }_{\mathrm{G} 324 \mathrm{E}}\right) \\
\text { SFV(PDE }\end{array}$ & $\begin{array}{l}\text { Temperature-sensitive in primary rat hippocampal } \\
\text { neurons, expresses at } 31^{\circ} \mathrm{C} \text { but little at } 37^{\circ} \mathrm{C}\end{array}$ & $(39)$ \\
\hline $\begin{array}{l}\text { SFV(nsP2S259P,R649D,M780TnsP4G153E) } \\
\text { SFV(PDTE) }\end{array}$ & $\begin{array}{l}\text { Transduces both pyramidal cells and interneurons } \\
\text { of rat hippocampal slices at } 31^{\circ} \mathrm{C} \text { but not at } 37^{\circ} \mathrm{C}\end{array}$ & $(39)$ \\
\hline \multirow[t]{2}{*}{ SFV(A774nsP) } & $\begin{array}{l}\text { Transduces selectively glial cells at } 37^{\circ} \mathrm{C} \text {, and only } \\
\text { neurons at } 31^{\circ} \mathrm{C} \text { in primary rat hippocampal cells }\end{array}$ & $d$ \\
\hline & $\begin{array}{l}\text { Transduces selectively glia and other non-neuronal } \\
\text { cells at } 37^{\circ} \mathrm{C} \text {, but also neurons at } 31^{\circ} \mathrm{C} \text { in rat } \\
\text { hippocampal slices }\end{array}$ & $d$ \\
\hline
\end{tabular}

Note that SIN vectors also efficiently transduce hippocampal neurons in primary culture $(30,31)$, in slices $(27,32)$, and in vivo (30).

${ }^{a}$ The conventional vectors SFV1 (13) and SFV2gen (19) are based upon the cDNA for SFV4 that is derived from the wild-type, virulent L10 strain (5).

${ }^{b}$ Plus unpublished data by K. Lundstrom, A. Abenavoli, A. Malgaroli, and M.U. Ehrengruber.

${ }^{c}$ K. Lundstrom, and M.U. Ehrengruber, unpublished data.

${ }^{d}$ M.U. Ehrengruber, M. Renggli, M.J.V. Vähä-Koskela, A.E. Hinkkanen, and K. Lundstrom, unpublished data.

M.U. Ehrengruber, unpublished data). Furthermore, when a mutation in nsP2 known to confer replication-persistence (Leu713Pro; ref. 51) was inserted into SFV(PD), the resulting vector SFV(PD713P) was noncytopathic in BHK cells and still infected neurons in hippocampal slice cultures (K. Lundstrom, and M.U. Ehrengruber, unpublished data).

Taken together, the less cytopathic SFV and SIN mutants will permit the application of alphaviral vectors under more physiological conditions. In addition to general overexpression of recombinant proteins, the vectors can also be used to study expression kinetics and signal transduction events (54), suppress genes by antisense and ribozyme approaches, and perform gene therapy trials with prolonged gene expression.

\section{Vectors with Temperature-Dependent Regulation}

In present SFV and SIN vectors, transgene expression relies on the endogenous 26S subgenomic RNA promoter. The minimal 26S subgenomic RNA promoter consists of 19 nucleotides upstream and 5 nucleotides down- 
stream of the transcription start site for the subgenomic RNA, but its activity is enhanced when neighboring sequences are included (1). The 26S subgenomic RNA promoter functions in the cytoplasm of infected cells, as it is the compartment where the transcription of alphaviruses occurs (cf Fig. 1). In contrast, the nucleus is the compartment where "nonalphaviral" promoters are functional that can be regulated and transcribe RNA from DNA. Thus, other means to control SFV and SINmediated transgene expression have to be found. Temperature-dependence is one of the few ways to regulate alphavirus vectors that replicate and are transcribed in the cytoplasm.

Temperature-sensitive mutations have been described for SIN in each of the nsP genes $(55,56)$, and those in nsP4 (14) have been introduced into SIN expression vectors (57). Combination of the Pro726Ser change in nsP2 with a temperature-sensitive mutation in nsP4 led to the inducible expression of DNA-based vectors in a variety of cell lines (57). Several of the known temperature-sensitive point mutations in $n s P 2$ and $n s P 4$ have also been introduced into the SFV expression vector, causing temperature-sensitive transgene expression in cell lines, primary hippocampal neurons, and organotypic hippocampal slices (see Tables 3 and 4) (39). A quadruple-mutant vector, SFV(PDTE), with three point mutations in nsP2 and one in nsP4, permitted GFP expression at $31^{\circ} \mathrm{C}$ but not at $37^{\circ} \mathrm{C}$. Similarly, SFV(PD713P) permitted transgene expression at $31^{\circ} \mathrm{C}$ rather than $37^{\circ} \mathrm{C}(\mathrm{K}$. Lundstrom and M.U. Ehrengruber, unpublished data). Interestingly, the triple-mutant vector $\mathrm{SFV}\left(\mathrm{PDE}_{153}\right)$ when used at $37^{\circ} \mathrm{C}$ transduced interneurons, rather than pyramidal cells in rat hippocampal slices, characterized by a ratio of approx 0.6 between GFP-positive pyramidal cells and interneurons (the corresponding ratio is $>10$ for the wild-type SFV vector) (28). When SFV(PDE 153$)$ was used at $31^{\circ} \mathrm{C}$ instead, a wildtype phenotype was observed with a ratio of approx 10 (39). A different study revealed another SFV mutant, SFV(A774nsP) encoding GFP downstream of the $n s P$ genes from the avirulent SFV strain A7(74), to transduce glial cells, and not neurons, in cultured hippocampal cells and slices at $37^{\circ} \mathrm{C}$, whereas this was reversed at $31^{\circ} \mathrm{C}$ (M.U. Ehrengruber, M. Renggli, M.J.V. Vähä-Koskela, and K. Lundstrom, unpublished data). These results show that mutant alphaviral vectors are useful, at least in hippocampal tissue, to target transgene expression to a subset of neurons or even glial cells rather than principal neurons. At the non-permissive temperature, the host cellular environment presumably does not support alphaviral replication.

\section{Vectors with Decreased Expression Levels}

For many applications, the elevated expression levels obtained with alphaviral vectors are normally favorable or non-problematic. On the other hand, they may be detrimental under specific conditions - in particular when the overexpressed protein has cytotoxic effects or when more physiological levels of the expressed protein are essential (the functional expression of G protein-coupled receptors, e.g., may require a more physiological ratio of receptors vs $G$ proteins). To achieve lower expression levels, several point mutations were introduced into the 26S subgenomic RNA promoter of SFV (see Table 3) (58). The resulting levels of reporter protein $(\beta$-galactosidase and luciferase) expressed in BHK cells were only 1,3 , and $30 \%$, as compared to the quantities expressed from wild-type SFV vectors. The down-regulated expression vectors will thus permit examination of recombinant protein function under conditions that are more similar to the in situ situation. The use of the GFP reporter in combination with the more downregulated SFV vectors, however, will no longer be practical (transduced cells will not be recognized due to low GFP fluorescence).

\section{Comparison with Other Viral Vectors}

Many viruses have been successfully employed to transfer genes into neurons, and 

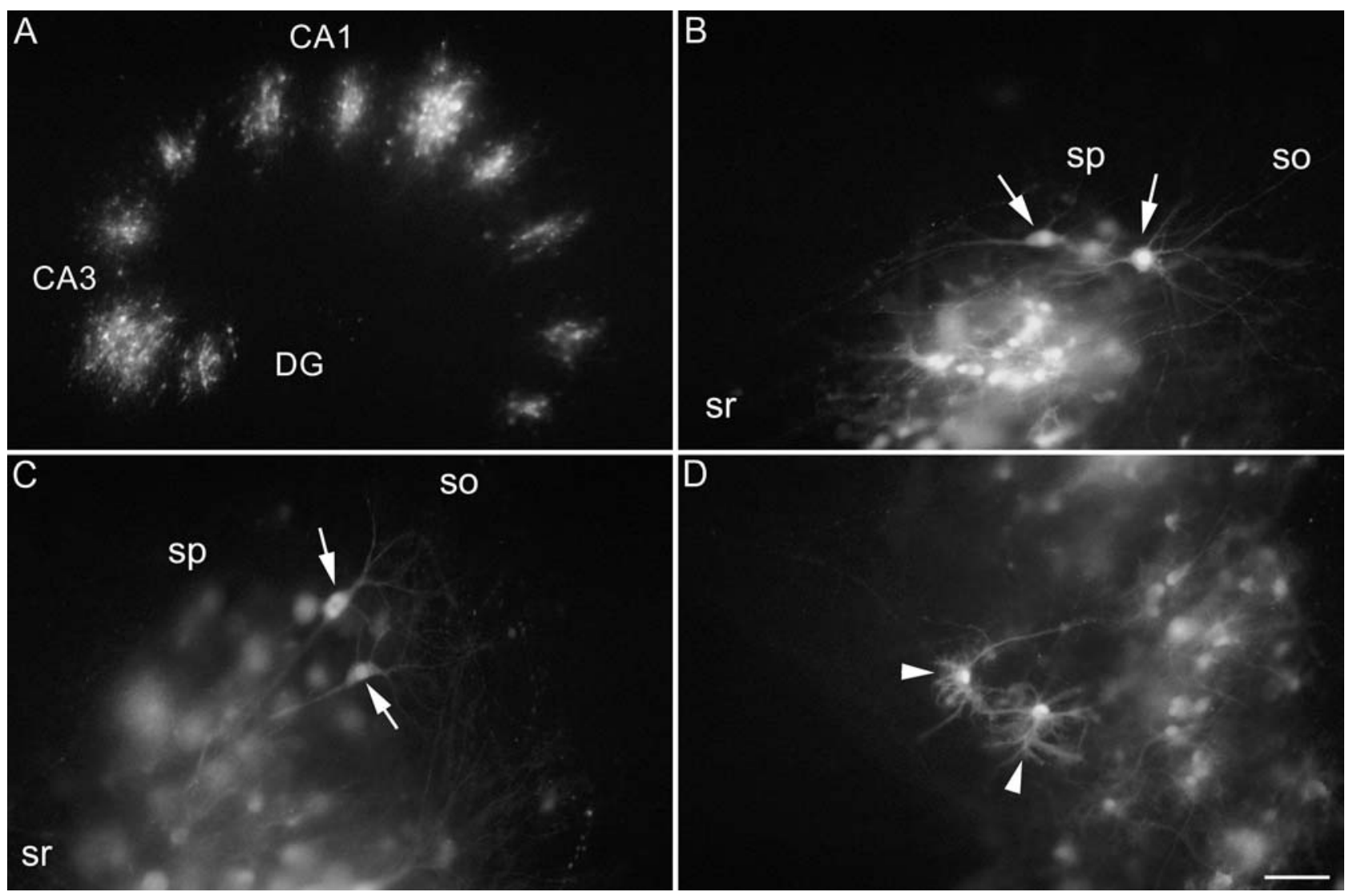

Fig. 5. Transduction of rat hippocampal slices with a lentiviral vector. P6 rat hippocampal slices at $28 \mathrm{~d}$ in culture were injected in the CA1 and CA3 pyramidal cell layer with two-fold diluted lentivirus expressing GFP under a CMV promoter. Slices were incubated at $37^{\circ} \mathrm{C}$ and fixed at $7 \mathrm{~d}$ post-infection. Fluorescence micrographs of a whole slice (A), CA1 neurons (B), arrows, CA3 pyramidal cells (C), arrows, and glial cells in the CA1 region (D), arrowheads. Abbreviations: DG, dentate gyrus; so, stratum oriens; sp, stratum pyramidale; sr, stratum radiatum. Bar: $260 \mu \mathrm{m}$ (A), $65 \mu \mathrm{m}$ (B-D).

each viral vector has its advantages and disadvantages. As each vector system has normally been established in a different laboratory and tested under distinct conditions, it is sometimes difficult for a newcomer to choose a viral vector that is optimal for study. We have previously characterized wild-type SFV and SFV(PD) vectors, recombinant adenovirus type 5, adeno-associated virus type 2 (AAV), lentivirus, and measles virus by their expression of GFP in rat hippocampal slice cultures (28). Figure 5 illustrates the results obtained with a lentivirus expressing GFP under the control of a cytomegalovirus (CMV) promoter. Both SFV vectors transduced more neurons (>90\% of all GFP-positive cells) than AAV, lentivirus, and measles virus $(71,69$, and $62 \%$, respectively), while resting membrane potential and conductance, action potentials, firing accommodation, and H-current appeared normal in all infected CA1 pyramidal cells. No infected neurons were identified with adenovirus type 5 (28). This was an unexpected finding because this virus is useful to transduce primary rat hippocampal neurons (59), although relatively high titers (approx $10^{8}$ 
plaque-forming units $/ \mathrm{mL}$ ) have to be applied to overcome the predominant glial cell infection. AAV-mediated GFP expression was restricted to neurons when the neuron-specific PDGF promoter (for platelet-derived growth factor $\beta$-chain) rather than the CMV promoter was used. Whereas transgene expression mediated by SFV was rapid but transient (as described above), it increased more slowly but remained stable with AAV and lentivirus, but was fast with measles virus. As no replicationimpaired system is available for measles virus, this vector propagated in the hippocampal slices. It is noteworthy that spreading occurred to pyramidal cells rather than non-neuronal cells (60), which may facilitate the selective transduction of most pyramidal cells within a slice culture. In any case, SFV is useful for short-term and AAV and lentivirus for longterm transduction of hippocampal slices, while measles virus may permit both short-and longterm transduction.

A qualitative evaluation of the maximal GFP expression levels obtained in hippocampal slice cultures revealed the following order: measles virus $\geq \mathrm{SFV} \approx$ lentivirus $>\mathrm{AAV}$. Compared to GFP-expressing lentivirus, the identification of neurons transduced with SFV and SIN vectors encoding GFP was easier (cf Fig. $4 \mathrm{~A}$ vs Fig. 5). We also estimated the transduction efficiencies in hippocampal slices by comparing the number of GFP positive cells vs the number of applied virus particles. The following order was found: wild-type SFV $\approx$ $\mathrm{SFV}(\mathrm{PD})>$ measles virus $>$ lentivirus $\approx \mathrm{AAV}-$ PDGF-GFP > AAV-CMV-GFP (28). For SFV and $S F V(P D)$, nearly every virus particle resulted in a GFP-positive cell. This high infection rate is due to the broad host range of the virus, and the fact that entry of one virus particle suffices to initiate viral replication in a host cell $(1,61)$. For SIN vectors in organotypic hippocampal slices, similar results as with SFV vectors are obtained (27). In addition to the high infection rate, the easy generation of high-titer virus stocks $(36,37)$ that contain a high ratio of infectious to physical particles (61) makes SFV and SIN vectors favorable for gene transfer into neurons. In several countries, SFV vectors packaged with pSFVHelper2 may be preferred as they are classified as biosafety level 1.

\section{Acknowledgments}

This review article is dedicated to the memory of my former postdoctoral advisor Dr. Norman Davidson (April 5, 1916 to February 14, 2002). The author's work is supported by grant no. 31-57125.99 from the Swiss National Science Foundation. Thanks to Drs. Antonio Malgaroli and R. Anne McKinney for providing the confocal images of Figure 4; Martin Renggli for editing Figure 3; Roland Schöb for editing Figure 4; and Drs. Sondra Schlesinger and Kenneth Lundstrom for comments on the manuscript.

\section{References}

1. Schlesinger S. and Schlesinger M. J. (2001) Togaviridae: the viruses and their replication, in Fields Virology. (Knipe D. M. and Howley P. M., eds.) Lippincott Williams \& Wilkins, Philadelphia, pp. 895-916.

2. Smithburn K. C. and Haddow A. J. (1944) Semliki Forest virus. I. Isolation and pathogenic properties. J. Immunol. 49, 141-147.

3. Taylor R. M., Hurlbut H. S., Work T. H., Kingsbury J. R., and Frothingham T. E. (1955) Sindbis virus: a newly recognized arthropod-transmitted virus. Am. J. Trop. Med. Hyg. 4, 844-846.

4. Kubes V. and Rios F. A. (1939) The causative agent of infectious equine encephalomyelitis in Venezuela. Science 90, 21.

5. Griffin D. E. (2001) Alphaviruses in Fields Virology. (Knipe D. M. and Howley P. M., eds.) Lippincott Williams \& Wilkins, Philadelphia, pp. 917-962.

6. Bradish C. J., Allner K., and Maber H. B. (1971) The virulence of original and derived strains of Semliki Forest virus for mice, guinea pigs, and rabbits. J. Gen. Virol. 12, 141-160.

7. Fazakerley J. K., Pathak S., Scallan M., Amor S., and Dyson H. (1993) Replication of the A7(74) strain of Semliki Forest virus is restricted in neurons. Virology 195, 627-637. 
8. Oliver K. R., Scallan M. F., Dyson H., and Fazakerley J. K. (1997) Susceptibility to a neurotropic virus and its changing distribution in the developing brain is a function of CNS maturity. J. Neurovirol. 3, 38-48.

9. Griffin D. E. (1998) A review of alphavirus replication in neurons. Neurosci. Biobehav. Rev. 22, 721-723.

10. Peränen J., Takkinen K., Kalkkinen N., and Kääriäinen L. (1988) Semliki Forest virus-specific non-structural protein nsP3 is a phosphoprotein. J. Gen. Virol. 69, 2165-2178.

11. LaStarza M. W., Lemm J. A., and Rice C. M. (1994) Genetic analysis of the nsP3 region of Sindbis virus: evidence for roles in minusstrand and subgenomic RNA synthesis. J. Virol. $68,5781-5791$.

12. Davis N. L., Willis L. V., Smith J. F., and Johnston R. E. (1989) In vitro synthesis of infectious venezuelan equine encephalitis virus RNA from a cDNA clone: analysis of a viable deletion mutant. Virology 171, 189-204.

13. Liljeström P. and Garoff H. (1991) A new generation of animal cell expression vectors based on the Semliki Forest virus replicon. BioTechnology 9, 1356-1361.

14. Xiong C., Levis R., Shen P., Schlesinger S., Rice C. M., and Huang H. V. (1989) Sindbis virus: an efficient, broad host range vector for gene expression in animal cells. Science 243, 1188-1191.

15. Bredenbeek P. J., Frolov I., Rice C. M., and Schlesinger S. (1993) Sindbis virus expression vectors: packaging of RNA replicons by using defective helper RNAs. J. Virol. 67, 6439-6446.

16. Lundstrom K. (1999) Alphaviruses as tools in neurobiology and gene therapy. J. Recept. Signal Transduct. Res. 19, 673-686.

17. Schlesinger S. (2001) Alphavirus vectors: development and potential therapeutic applications. Expert Opin. Biol. Ther. 1, 177-191.

18. Hahn C. S., Hahn Y. S., Braciale T. J., and Rice C. M. (1992) Infectious Sindbis virus transient expression vectors for studying antigen processing and presentation. Proc. Natl. Acad. Sci. USA 89, 2679-2683.

19. Malherbe P., Kratzeisen C., Lundstrom K., Richards J. G., Faull R. L. M., and Mutel V. (1999) Cloning and functional expression of alternative spliced variants of the human metabotropic glutamate receptor 8. Mol. Brain Res. 67, 201-210.
20. Polo J. M., Belli B. A., Driver D. A., et al. (1999) Stable alphavirus packaging cell lines for Sindbis virus and Semliki Forest virus-derived vectors. Proc. Natl. Acad. Sci. USA 96, 4598-4603.

21. Schlesinger S. (1993) Alphaviruses - vectors for the expression of heterologous genes. Trends Biotechnol. 11, 18-22.

22. DiCiommo D. P. and Bremner R. (1998) Rapid, high level protein production using DNAbased Semliki Forest virus vectors. J. Biol. Chem. 273, 18,060-18,066.

23. Koller D., Ruedl C., Loetscher M., et al. (2001) A high-throughput alphavirus-based expression cloning system for mammalian cells. Nat. Biotechnol. 19, 851-855.

24. Atkins G. J., Sheahan B. J., and Liljeström P. (1999) The molecular pathogenesis of Semliki Forest virus: a model virus made useful? J. Gen. Virol. 80, 2287-2297.

25. Olkkonen V. M., Liljeström P., Garoff H., Simons K., and Dotti C. G. (1993) Expression of heterologous proteins in cultured rat hippocampal neurons using the Semliki Forest virus vector. J. Neurosci. Res. 35, 445-451.

26. Wittemann S., Mark M. D., Rettig J., and Herlitze S. (2000) Synaptic localization and presynaptic function of calcium channel $\beta 4$-subunits in cultured hippocampal neurons. J. Biol. Chem. $275,37,807-37,814$.

27. Ehrengruber M. U., Lundstrom K., Schweitzer C., Heuss C., Schlesinger S., and Gähwiler B. H. (1999) Recombinant Semliki Forest virus and Sindbis virus efficiently infect neurons in hippocampal slice cultures. Proc. Natl. Acad. Sci. USA 96, 7041-7046.

28. Ehrengruber M. U., Hennou S., Büeler H., Naim H. Y., Déglon N., and Lundstrom K. (2001) Gene transfer into neurons from hippocampal slices: comparison of recombinant Semliki Forest virus, adenovirus, adeno-associated virus, lentivirus, and measles virus. Mol. Cell. Neurosci. 17, 855-871.

29. Lundstrom K., Richards J. G., Pink J. R., and Jenck F. (1999) Efficient in vivo expression of a reporter gene in rat brain after injection of recombinant replication-deficient Semliki Forest virus. Gene Ther. Mol. Biol. 3, 15-23.

30. Gwag B. J., Kim E. Y., Ryu B. R., et al. (1998) A neuron-specific gene transfer by a recombinant defective Sindbis virus. Mol. Brain Res. 63, 53-61. 
31. Osten P., Khatri L., Perez J. L., et al. (2000) Mutagenesis reveals a role for ABP/GRIP binding to GluR2 in synaptic surface accumulation of the AMPA receptor. Neuron 27, 313-325.

32. Maletic-Savatic M., Malinow R., and Svoboda K. (1999) Rapid dendritic morphogenesis in CA1 hippocampal dendrites induced by synaptic activity. Science 283, 1923-1927.

33. Gähwiler B. H. (1981) Organotypic monolayer cultures of nervous tissue. J. Neurosci. Methods 4, 329-342.

34. Stoppini L., Buchs P.-A., and Muller D. (1991) A simple method for organotypic cultures of nervous tissue. J. Neurosci. Methods 37, 173-182.

35. Malinow R., Hayashi Y., Maletic-Savatic M., Zaman S. H., Poncer J.-C., Shi S.-H., and Esteban J. A. (2000) Introduction of green fluorescent protein into hippocampal neurons through viral infection, in Imaging Neurons: $A$ Laboratory Manual (Yuste R., Lanni F., and Konnerth A., eds.) CSHL Press, Cold Spring Harbor, pp. 58.1-58.8.

36. Ehrengruber M. U. and Lundstrom K. (2000) Alphavirus-mediated gene transfer into neurons, in Current Protocols in Neuroscience. (Crawley J. N., Gerfen C. R., Rogawski M. A., Sibley D. R., Skolnick P., and Wray S., eds.), John Wiley \& Sons, New York, pp. 4.22.1-4.22.23.

37. Ehrengruber M. U. and Lundstrom K. (2002) Semliki Forest virus and Sindbis virus vectors, in Current Protocols in Human Genetics. (Dracopoli N. C., Haines J. L., Korf B. R., et al. eds.) John Wiley \& Sons, New York, pp. 12.2.1-12.2.23.

38. Lundstrom K., Schweitzer C., Richards J. G., Ehrengruber M. U., Jenck F., and Mülhardt C. (1999) Semliki Forest virus vectors for in vitro and in vivo applications. Gene Ther. Mol. Biol. 4, 23-31.

39. Lundstrom K., Rotmann D., Hermann D., Schneider E. M., and Ehrengruber M. U. (2001) Novel mutant Semliki Forest virus vectors: gene expression and localization studies in neuronal cells. Histochem. Cell Biol. 115, 83-91.

40. Shi S.-H., Hayashi Y., Petralia R. S., Zaman S. H., Wenthold R. J., Svoboda K., and Malinow R. (1999) Rapid spine delivery and redistribution of AMPA receptors after synaptic NMDA receptor activation. Science 284, 1811-1816.

41. Ehrengruber M. U., Muhlebach S. G., Söhrman S., Leutenegger C., M., Lester H. A., and Davidson N. (2000) Modulation of early growth response (EGR) transcription factor-dependent gene expression by using recombinant adenovirus. Gene 258, 63-69.

42. Nehring R. B., Horikawa R. P. M., El Far O., et al. (2000) The metabotropic $\mathrm{GABA}_{B}$ receptor directly interacts with the activating transcription factor 4. J. Biol. Chem. 275, 35,185-35,191.

43. Lundstrom K., Mills A., Buell G., Allet E., Adami N., and Liljeström P. (1994) High-level expression of the human neurokinin-1 receptor in mammalian cell lines using the Semliki Forest virus expression system. Eur. J. Biochem. 224, 917-921.

44. Monastyrskaia K., Lundstrom K., Plahl D., Acuna G., Schweitzer C., Malherbe P., and Mutel V. (1999) Effect of the umami peptides on the ligand binding and function of rat mGlu4a receptor might implicate this receptor in the monosodium glutamate taste transduction. $\mathrm{Br}$. J. Pharmacol. 128, 1027-1034.

45. Schweitzer C., Kratzeisen C., Adam G., et al. (2000) Characterization of [(3)H]-LY354740 binding to rat mGlu2 and mGlu3 receptors expressed in $\mathrm{CHO}$ cells using Semliki Forest virus vectors. Neuropharmacology 39, 1700-1706.

46. Lundstrom K., Vargas A., and Allet B. (1995) Functional activity of a biotinylated human neurokinin 1 receptor fusion expressed in the Semliki Forest virus system. Biochem. Biophys. Res. Commun. 208, 260-266.

47. Scheer A., Björklöf K., Cotecchia S., and Lundstrom K. (1999) Expression of the $\alpha_{1 b}$-adrenergic receptor and $G$ protein subunits in mammalian cell lines using the Semliki Forest virus expression system. J. Recept. Signal Transduct. Res. 19, 369-378.

48. Gorrie G. H., Vallis Y., Stephenson A., Whitfield J., Browning B., Smart T. G., and Moss S. J. (1997) Assembly of GABAA receptors composed of $\alpha 1$ and $\beta 2$ subunits in both cultured neurons and fibroblasts. J. Neurosci. 17, 6587-6596.

49. Dryga S. A., Dryga O. A., and Schlesinger S. (1997) Identification of mutations in a Sindbis virus variant able to establish persistent infection in BHK cells: the importance of a mutation in the nsP2 gene. Virology 228, 74-83.

50. Agapov E. V., Frolov I., Lindenbach B. D., Pragai B. M., Schlesinger S., and Rice C. M. (1998) Non-cytopathogenic Sindbis RNA vectors for heterologous gene expression. Proc. Natl. Acad. Sci. USA 95, 12,989-12,994.

51. Perri S., Driver D. A., Gardner J. P., Sherrill S., Belli B. A., Dubensky T. W., Jr., and Polo J. M. 
(2000) Replicon vectors derived from Sindbis virus and Semliki Forest virus that establish persistent replication in host cells. J. Virol. 74, 9802-9807.

52. Rikkonen M. (1996) Functional significance of the nuclear-targeting and NTP-binding motifs of Semliki Forest virus nonstructural protein nsP2. Virology 218, 352-361.

53. Fazakerley J. K., Boyd A., Mikkola M. L., and Kääriäinen L. (2002) A single amino acid change in the nuclear localization sequence of the nsP2 protein affects the neurovirulence of Semliki Forest virus. J. Virol. 76, 392-396.

54. Mazzucchelli C., Vantaggiato C., Ciamei A., et al. (2002) Knockout of ERK1 MAP kinase enchances synaptic plasticity in the striatum and facilitates striatal-mediated lerning and memory. Neuron 34, 807-820.

55. Hahn Y. S., Grakoui A., Rice C. M., Strauss E. G., and Strauss J. H. (1989) Mapping of RNAtemperature-sensitive mutants of Sindbis virus: complementation group F mutants have lesions in nsP4. J. Virol. 63, 1194-1202.

56. Hahn Y. S., Strauss E. G., and Strauss J. H. (1989) Mapping of RNA- temperature-sensitive mutants of Sindbis virus: assignment of complementation groups $A, B$, and $G$ to nonstructural proteins. J. Virol. 63, 3142-3150.

57. Boorsma M., Nieba L., Koller D., Bachmann M. F., Bailey J. E., and Renner W. A. (2000) A temperature-regulated replicon-based DNA expression system. Nature Biotech. 18, 429-432.

58. Lundstrom K., Ziltener P., Hermann D., Schweitzer C., Richards J. G., and Jenck F. (2001) Improved Semliki Forest virus vectors for receptor research and gene therapy. J. Recept. Signal Transduct. Res. 21, 55-70.

59. Ehrengruber M. U., Doupnik C. A., Xu Y., Garvey J., Jasek M. C., Lester H. A., and Davidson N. (1997) Activation of heteromeric G proteingated inward rectifier $\mathrm{K}^{+}$channels overexpressed by adenovirus gene transfer inhibits the excitability of hippocampal neurons. Proc. Natl. Acad. Sci. USA 94, 7070-7075.

60. Ehrengruber M. U., Ehler E., Billeter M. A., and Naim H. Y. (2002) Measles virus spreads in rat hippocampal neurons by cell-to-cell contact and in a polarized fashion. J. Virol. 76, 5720-5728.

61. Strauss J. H. and Strauss E. G. (1994) The alphaviruses: gene expression, replication, and evolution. Microbiol. Rev. 58, 491-562.
62. Altman-Hamamdzic S., Groseclose C., Ma J.-X., Hamamdzic D., Vrindavanam N. S., Middaugh L. D., Parratto N. P., and Sallee F. R. (1997) Expression of $\beta$-galactosidase in mouse brain: utilization of a novel nonreplicative Sindbis virus vector as a neuronal gene delivery system. Gene Ther. 4, 815-822.

63. Knight D. E. (2000) Secreation from bovine chromaffin cells acutely expressing exogenous proteins using a recombinant Semliki Forest virus containing an EGFP reporter. Mol. Cell. Neurosci. 14, 486-505.

64. Allet B., Hochmann A., Martinoiu I., Berger A., Missotten M., Antonsson B., et al. (1996) Dissecting processing and apoptotic activity of a cysteine protease by mutant analysis. J. Cell Biol. 135, 479-486.

65. Kyttälä A., Heinonen O., Peltonen L., and Jalanko A. (1998) Expression and endocytosis of lysosomal aspartylglucosaminidase in mouse primary neurons. J. Neurosci. 18, 7756.

66. Park D. S., Levine B., Ferrari G., and Greene L. A. (1997) Cyclin dependent kinase inhibitors and dominant negative cyclin dependent kinase 4 and 6 promote survival of NGFdeprived sympathetic neurons. J. Neurosci. 17, 8975-8983.

67. Hayashi Y., Shi S.-H., Esteban J. A., Piccini A., Poncer J.-C., and Malinow R. (2000) Driving AMPA receptors into synapses by LTP and CaMKII: requirement for GluR1 and PDZ domain interaction. Science 287, 2262-2267.

68. Voets T., Toonen R. F., Brian E. C., de Wit H., Moser T., Rettig J., Südhof T. C., Neher E., and Verhage M. (2001) Munc18-1 promotes large dense-core vesicle docking. Neuron 31, 581-591.

69. Ashery U., Varoqueaux F., Voets T., Betz A., Thakur P., Koch H., Neher E., Brose N., and Rettig J. (2000) Munc13-1 acts as a priming factor for large dense-core vesicles in bovine chromaffin cells. EMBO J. 19, 3586-3596.

70. Chheda M. G., Ashery U., Thakur P., Rettig J., and Sheng Z. H. (2002) Phosphorylation of Snapin by PKA modulates its interaction with the SNARE complex. Nat. Cell Biol. 3, 331-338.

71. Lao G., Scheuss V., Gerwin C. M., Su Q., Mochida S., Rettig J., and Sheng Z. H. (2000) Syntaphilin: a syntaxin-1 clamp that controls SNARE assembly. Neuron 25, 191-201.

72. Okada M., Onodera K., Van Renterghem C., Sieghart W., and Takahashi T. (2000) Functional correlation of $\mathrm{GABA}_{\mathrm{A}}$ receptor $\alpha$ subunits 
expression with the properties of IPSCs in the developing thalamus. J. Neurosci. 20, 2202-2208.

73. Werner P., Kawashima E., Reid J., Hussy N., Lundstrom K., Buell G., Humbert Y., and Jones K. A. (1994) Organization of the mouse 5-HT3 receptor gene and functional expression of two splice variants. Mol. Brain Res. 26, 233-241.

74. Khakh B. S., Smith W. B., Chiu C. S., Ju D., Davidson N., and Lester H. A. (2001) Activation-dependent changes in receptor distribution and dendritic morphology in hippocampal neurons expressing $\mathrm{P}_{2} \mathrm{X}_{2}$-green fluorescent protein receptors. Proc. Natl. Acad. Sci. USA 98, 5288-5293.

75. Shi S.-H., Hayashi Y., Esteban J., and Malinow R. (2001) Subunit-specific rules governing AMPA receptor trafficking to synapses in hippocampal pyramidal neurons. Cell 105, 331-343.

76. Zhu J. J., Esteban J. A., Hayashi Y., and Malinow R. (2000) Postnatal synaptic potentiation: delivery of GluR4-containing AMPA receptors by spontaneous activity. Nat. Neurosci. 3, 1098-1106.

77. Okada T., Yamada N., Kakegawa W., Tsuzuki T., Kawamura M., Nawa H., Iino M., and Ozawa S. (2001) Sindbis viral-mediated expression of $\mathrm{Ca}^{2+}$-permeable AMPA receptors at hippocampal CA1 synapses and induction of NMDA receptor-independent long-term potentiation. Eur. J. Neurosci. 13, 1635-1643.

78. Iwakura Y., Nagano T., Kawamura M., Horikawa H., Ibaraki K., Takei N., and Nawa H. (2001) N-methyl- ${ }_{-}$-aspartate-induced $\alpha$ amino-3-hydroxy-5-methyl-4-isoxazoleproprionic acid (AMPA) receptor down-regulation involves interaction of the carboxyl terminus of GluR2/3 with Pick1: ligand-binding studies using Sindbis vectors carrying AMPA receptor decoys. J. Biol. Chem. 276, 40,025-40,032.

79. Takamori S., Rhee J. S., Rosenmund C., and Jahn R. (2001) Identification of differentiationassociated brain-specific phosphate transporter as a second vesicular glutamate transporter (VGLUT2). J. Neurosci. 21, RC182:1-6.

80. Takamori S., Rhee J. S., Rosenmund C., and Jahn R. (2000) Identification of a vesicular glutamate transporter that defines a glutamatergic phenotype in neurons. Nature 407, 189-194.

81. Owe-Larsson B., Berglund M., Kristensson K., Garoff H., Larhammar D., and Low P. (1999) Perturbation of the synaptic release machinery in hippocampal neurons by overexpression of
SNAP-25 with the Semliki Forest virus vector. Eur. J. Neurosci. 11, 1981-1987.

82. Wei S., Xu T., Ashery U., Kollewe A., Matti U., Antonin W., Rettig J., and Neher E. (2000) Exocytotic mechanism studied by truncated and zero layer mutants of the C-terminus of SNAP25. EMBO J. 19, 1279-1289.

83. Tobaben S., Thakur P., Fernandez-Chacon R., Südhof T. C., Rettig J., and Stahl B. (2001) A trimeric protein complex functions as a synaptic chaperone machine. Neuron 31, 687-699.

84. Okubo Y., Kakizawa S., Hirose K., and Iino M. (2001) Visualization of $\mathrm{IP}_{3}$ dynamics reveals a novel AMPA receptor-triggered $\mathrm{IP}_{3}$ production pathway mediated by voltage-dependent $\mathrm{Ca}^{2+}$ influx in Purkinje cells. Neuron 32, 113-122.

85. Simons M., De Strooper B., Multhaup G., Tienari P. J., Dotti C. G., and Beyreuther K. (2001) Amyloidogenic processing of the human amyloid precursor protein in primary cultures of rat hippocampal neurons. J. Neurosci. 16, 899-908.

86. Cook D. G., Sung J. C., Golde T. E., et al. (1996) Expression and analysis of presenilin 1 in a human neuronal system: localization in cell bodies and dendrites. Proc. Natl. Acad. Sci. USA 93, 9223-9228.

87. Ulmanen I., Peranen J., Tenhunen J., Tilgmann C., Karhunen T., Panula P., Bernasconi L., Aubry J. P., and Lundstrom K. (1997) Expresion and intracellular localization of catechol Omethyltransferase in transfected mammalian cells. Eur. J. Biochem. 243, 452-459.

88. Hama E., Shirotani K., Masumoto H., SekineAizawa Y., Aizawa H., and Saido T. C. (2001) Clearance of extracellular and cell-associated amyloid beta peptide through viral expression of neprilysin in primary neurons (Tokyo). J. Biochem 130, 721-726.

89. de Hoop M., von Poser C., Lange C., Ikonen E., Hunziker W., and Dotti C. G. (1995) Intracellular routing of wild-type and mutated polymeric immunoglobulin receptor in hippocampal neurons in culture. J. Cell Biol. 130, 1447-1459.

90. Frolov I., Agapov E., Hoffman T. A., Prágai B. M., Lippa M., Schlesinger S., and Rice C. M. (1999) Selection of RNA replicons capable of persistent noncytopathic replication in mammalian cells. J. Virol. 73, 3854-3865.

91. Berglund P., Sjöberg M., Garoff H., et al. (1993) Semliki Forest virus expression system: production of conditionally infectious recombinant particles. BioTechnology 11, 916-920. 